\title{
INDUSTRIAL DYNAMICS AND URBANIZATION IN THE NORTHEAST OF BRAZIL
}

\author{
dinâmicas industriais e urbanização no Nordeste do Brasil
}

\author{
Edilson Pereira Junior*
}

\begin{abstract}
Resumo
O contexto que materializa no espaço novas forças de aceleração dos objetos e dos fluxos, decorrentes da hegemonia de interesses econômicos, engendra uma mobilidade sem precedentes em escala local, nacional e mundial, ao integrar sistemas urbanos e regionais por meio de uma rede de relações comandadas por investimentos produtivos industriais. Ressalta-se os efeitos dessas mudanças na região Nordeste do Brasil, em especial sobre o seu processo de urbanização, que condiciona a divisão territorial do trabalho, os aspectos concernentes à reestruturação urbana e a articulação entre cidades e regiões. $\mathrm{O}$ artigo investiga essas questões considerando os diferentes impactos de três "configurações espaciais produtivas", responsáveis pela redefinição dos papeis centrais de algumas cidades e pela refuncionalização dos tradicionais arranjos da rede urbana nordestina, agora delineados por diferentes centralidades e conexões.
\end{abstract}

Palavras-chave: Metrópole; Reestruturação produtiva; Fragmentação da cidade; Centralidade.

\begin{abstract}
The context in which the forces of acceleration of objects and flows are materialized in space as a result of the hegemony of economic interests, engenders an unprecedented mobility on a local, national and global scale by integrating urban and regional systems through a network of relationships commanded by productive industrial investments. The effects of these changes in the Northeast region of Brazil are emphasized, especially regarding the urbanization process, which conditions the territorial division of labor, the aspects concerning urban restructuring and the articulation between cities and regions. The article investigates these issues, considering the different impacts of three productive spatial configurations, which are responsible for redefining the central roles of some cities and for changing the functioning of the traditional arrangements of the northeastern urban network, now delineated by different centralities and connections.
\end{abstract}

Key words: Metropolis, Productive restructuring, Fragmentation of the city; Centrality.

\begin{abstract}
Résumé
Le contexte qui reforce dansl'espace nouvelle logiques d'accélération des objets et des flux, résultant de l'hégémonie des intérêts économiques, engendre une mobilité sans précédent aux niveaux régional, national etmondial, enintégrant les systèmes urbains et régionaux à travers d'un réseau de relations contrôlées par des investissements productifs industriels. Soulignons les effets de ces changements dans le Nord-Est du Brésil, enparticulier sur son processus d'urbanisation, qui détermine la division territoriale du travail, les aspects liés à la restructuration urbaine et le lien entre les villes et les régions. L'article examine ces questions en considérant les différents impacts de trois "configurations spatiales productives", responsables de redéfinition des rôles centraux de certaines villes et dechangement des arrangements traditionnels du réseau urbain du Nord-Est, maintenant délimitées par différentes centralités et des connexions.
\end{abstract}

Mots clés: Métropole, Restructuration productive, Fragmentation de la ville; Centralité.

(*) Lecturer, Doctor of the State University of Ceará (Universidade Estadual do Ceará) - Av. Paranjana, 1700 Campus do Itaperi, CEP: 60740000, Fortaleza (CE), Brasil. Tel: (+55 85)31019778 - edilsonapjr@hotmail.com 


\section{INTRODUCTION}

The objective of this article is to interpret one of the most relevant aspects of urban and regional restructuring in Brazil in recent years, which emphasizes productive industrial configurations and their spatial agglomerations. Traditionally, industrial activity has been one of the principal conditioners of the expansion and organization of productive space, even as it has established a two-way relationship with the city, sometimes enjoying the numerous benefits of high concentrations of people and services, sometimes stimulating the assembly of infrastructure and the circulation of goods and information.

Currently, increasingly subjected to a diffuse network of territorial relationships that integrates people, merchandise, capital and information, industrial activity has incorporated changes linked directly both to productive engineering and the spatial coverage of its consumer market. These alterations engender quantitative and qualitative changes, affecting the distribution of industrial establishments within the metropolitan areas or in areas previously considered peripheral and distant.

As a result, old industrialized regions are going through important modifications or are experiencing industrial decline, whilst other regions without a manufacturing tradition adopt a project of accumulation based on the increased value of local production or attracting external investments, consolidating economic policies focused on entrepreneurial public actions and territorial and urban restructuring as a strategic condition of productive dynamization.

This article addresses all these issues on consideringthree productive spatial configurations that reflect directly on the organization of regional urban space in Brazil in recent decades. These configurations are: 1) Localized industrial systems; 2) The industrial zones formed by the installation of the most diverse types of investment; and 3) The industrial and port complexes.

The empirical object selected for the research is the Northeast region of Brazil, where these transformations occur in an expressive manner, above all because this is an area where very little of the industrial capital circulating in Brazil in the last 40 years ended up, but since the 1990s, as a result of national and international economic redefinitions it has reverted its role in the scaleof productive investments.

The debate intends to contribute to the analysis of the new features of Brazilian urbanization, defined from a set of transformations consolidated by more recent productive restructuring processes and translated through changes in urban networks and the different relationships established between the cities, regions and industrial investments.

\section{THE SPATIAL RECONFIGURATION OF INDUSTRY AND THE NEW PROCESS OF URBANIZATION IN BRAZIL AND IN THE NORTHEAST}

The economic restructuring that has taken place in recent decades has profoundly altered the industrial geography of the planet. Through advances in transport, in new information technology and flexible restructurings, the territory of productive articulation and consumption has taken on network logic. The productive industrial process, formerly restricted to the manufacturing sector, took on a new dimension: nowadays products are planned in one place, manufactured and assembled in other places and consumed globally; financial operations and stock and production control have started to be controlled by company headquarters in real time and in a diffuse manner. In traditionally industrializedareas, cities and regions have redefined their roles in the network of relationships; factories transfer to the interior of the country, or relocate to other countries with a weak mechanized industrial tradition.

In fact, relocation is a strategy of restructuring that deepens the modifications implanted through productive reengineering, through the relocation of branches or all of a company's units of production based on the technical and political advantages offered by different locations. This is 
the only way of combining management and territorial concepts of production, integrating models of productive flexibility and labor with access to new national and regional markets, capable of offering the minimization of production costs.

When this whole dynamic reached Brazilian urbanization, it promptly redefined the role of the state of São Paulo and the Metropolitan Region of São Paulo (MRSP), which in 1970 concentrated, respectively, 48\% and 34\% of formal industrial employment in Brazil; by 2010 this participation had fallen to 30\% and 14\% (Annual Social Information Report - RAIS of the Ministry of Labor and Employment - MTE). The movement of deconcentration was not that radical and did not cause complete ruptures in the productive logic, because as demonstrated by the RAIS indicator, there is still a significant rate of concentration in industrial jobs in these two areas. However, the movement of expansion of the industry to a more diffuse portion of the territory is evident. The centrifugal forces of diseconomies of agglomeration affected the attractive capacity of investment in traditionally productive regions, principally in the MRSP, whilst numerous other centripetal forces in metropolitan regions and medium-sized cities or regional centers, in the most diverse regions of Brazil, have created strong productive agglomerations.

Within this deconcentration, the concentrated area (SANTOS; Silveira, 2001) is still prominent. In the same way, the movement of "concentrated deconcentration", presented by Góis Sobrinho and Azzoni (2014), is still present, demonstrating that the diffusion of the diverse industrial genres has a demarcated reach, primarily favoring the states of the South and Southeast regions.

The diffusion of industrial activity, however, even establishing itself more solidly in the states with a tradition of manufacturing production, does not hide the increasingly rapid movement of deconcentration to other Brazilian regions. At the beginning of the 1990s, De Negri (1994) had already identified that between 1970 and 1990 the Southeast region's participation in national industrial production had fallen gradually, whilst in other regions participation had risen. In 2014, a report released by National Confederation of Industry (CNI), confirmed this thesis: in other words, even though they concentrate the most important industrial activity in the country, the South and Southeast regions are growing less than other regions in the sector, revealing that a set of economic and political forces is inducing the relocation of industrial activity in the country. The CNI (NATIONAL CONFEDERATION OF INDUSTRY - CNI, 2014) data reveals that between 2002 and 2012, while the South and Southeast regions had a negative variation in their participation in the industrial GDP, with rates of $-2.1 \%$ and $1.7 \%$ respectively, the North, Center-west and Northeast presented a positive variation in the same indicator, reaching growth rates of $1.9 \%, 1.3 \%$ and $0.6 \%$.

On evaluating the performance of the states in the same period, the report also identified a negative variation - if positive this was very modest - in the participation of industrial GDP for those that traditionally had a larger productive tradition, considering the rates presented by São Paulo (-5.2\%), Paraná (-4.5\%), Rio Grande do Sul (-2.8\%), Santa Catarina (0.3\%) and Minas Gerais $(0.8 \%)$.In contrast, the report revealed that the variation of industrial GDP grew greatly or also remained positive in states like Pará (7.6\%), Mato Grosso do Sul (5.0\%), Rondônia (4.4\%), Pernambuco (3 5\%), Piauí (3.2\%), Goiás (2.4\%) and Ceará (0.2\%). In the case of Rio de Janeiro, a particular movement should be interpreted; there was a noteworthy variation in the industrial GDP (it grew 7.9\% between 2002 and 2012), especially due to the strengthening of investments in the petroleum and gas industry.

This is not a sudden movement and has its origins in the regional development policies implemented a few decades ago (the Superintendency for the Development of the Northeast and the Superintendency of Development for the Amazon - SUDENE and SUDAM, and the Free Zone of Manaus, for example).However, other factors tend to accentuate it, strengthening the centrifugal forces of the diffusion of industrial production in the territory, such as the battle of locations, the productive restructuring of companies, export incentive policies, the greater integration of the national market, the expansion of urbanization in the Northeast, North and Center-west, the relocation 
of the agricultural and mineral frontier and technological transformations (GÓIS SOBRINHO; AZZONI, 2014; SANTOS; SILVEIRA, 2001; DINIZ; CROCCO, 1996; and DE NEGRI, 1994).

Furthermore, there is the fact that the activities linked to decision making, the technological innovation of goods and after sales services are increasingly agglomerating in the larger metropolitan centers(LENCIONI, 1994). Meanwhile, production lines in factories and the productive activities in the more traditional sectors tend to spread through the region and territory, confirming that the overflow of the productive dynamics is associated with the deepening of the new process of urbanization in Brazil (SPOSITO, 2015; CORREAA, 2011; SANTOS, 2005).

In the ambit of the Northeast region, on the treadmill of transformations engendered over the last two decades, another industrial structure has become visible whose most striking features are technological modernization, the arrival of new types of production and the location of productive units in places with a low manufacturing tradition. Thus, the diversification of the investments, mainly from the Southeast and South of Brazil are added to the dynamization of the areas with the greatest mechanized industrialproduction and the productive expansion of the new industrial centers.

In addition, the change in location of companies' production units involves above all the traditional genres of industries that employ large amounts of labor, whilst the sectors that have made the biggest efforts in technological innovation remain in the country's more traditional centers. Even so, these transformations promote profound impacts on the urban network, installing new vectors of economic expansion in certain areas, all geared towards the growth of productive standards and modern consumption, which implies changes in the functions and interactions of the cities.

As the region with the most ancient settlements in the Brazilian territory and with regional areas of semi-arid climate that are among the most populated in the world, the occupation of the Northeast has organized itself to benefit the agricultural oligarchies with a strong political presence, who structure their power from the articulation with commercial and industrial bourgeois groups, shaping the social, political and economic regional structure.

With the programs developed by the Superintendency for the Development of the Northeast (SUDENE) in the 1960s, 1970s and 1980s, the region ensured the implantation of industrial projects within the centralized regional planning strategies, dynamizing the economic picture. The way in which the distribution of industrial investment was carried out between the states of the Northeast at this time is a symbol of the unequal spatial configuration that marks its economic and political structure. It privileged areas that were already structured and had political power strong enoughto attract financing and resources, evidencing an accentuated spatial concentration of investments. The locational competitive advantages highlighted the cities of Salvador, Recife and Fortaleza as the capitals that were the most propitious for the implantation of industry, due to their good infrastructure.

On the treadmill of transformations engendered by the economic opening in Brazil in the 1990s, another economic structure became visible in the Northeast, above all when concerning the new technical systems, the industrial activity, the modern services and agribusiness. Investments increased, which resulted in a reconfiguration of the interurban division of labor, intensifying traits of inequality, but also restructuring the role of the old areas, especially by redefining the ties of submission and command in the regional urban arrangements.

However, the dynamics that occurred in the last two decades are those that mark the most significant productive and urban transformations in the region. They bring together the effects of the battle of locations undertaken by various states in the Northeast with the intention of attracting industrial enterprises, with a macroeconomic policy developed by the last three federal governments, that culminated in a wave of public and private investments, which are responsible for a requalification of the term "problem region", widely used in the past.

The regional performance of some variables strengthens this trend. According to data from the Bank of the Northeast of Brazil (BNB, 2015), the nominal growth in the volume of resources invested by the institution rose from $\mathrm{R} \$ 2.6$ billion (through 686 operations) in 2002 to $\mathrm{R} \$ 25.3$ billion 
(with 4.7 million operations) in 2015. Other positive indicators are added to the above, in particular the expansion of exports, which increased from R $\$ 3.3$ billion in 1999 to $\mathrm{R} \$ 18.8$ billion in 2011 (MDCI, 2012); and the data for the nominal GDP, which increased from R $\$ 191.5$ billion in 2002 to $\mathrm{R} \$ 555.3$ billion in 2011 (IBGE, 2013). Another example are the actions of the Accelerated Growth Program (PAC), which since 2008 has made significant investments in the region's infrastructure (logistics, energy, social and urban), totaling R $\$ 503.9$ billion

From the same perspective, in a study on the region published in 2008 by the National Confederation of Industry (CNI), entitled Revista Indústria Brasileira, the institution analyzed the state profiles and concluded that the Northeast "was experiencing a new phase" with "growth above the country's average" (CNI, 2008). Also according to the aforementioned publications, the Industrial Manufacturing Value (VTI) in the Northeast rose by 25.7\% between 1996 and 2005, increasing its participation in Brazilian industry from 7.5\% to 9.3\% (CNI, 2008). With the continuity of the investments, between 2002 and 2010, the number of formal workers in the sector more than doubled, jumping from 800 thousand to 1.7 million.

All of this data also reveals that the most recent rhythms of economic dynamism continue to be articulated with an intervention project of exogenous forces, which implies a more complex reading of the scale of the synchronic and diachronic processes of the current spatial organization of industry in the Northeast.

In fact, business groups of great importance from various countries or the states in the South and Southeast regions have responded positively to the offer of numerous benefits. Among the companies that have done this are: Grendene, Vulcabrás / Azaleia, Dakota and Alpargatas (footwear); Vicunha and Coteminas (textiles); Marisol, Malwee, Villa Romana, and Hering (clothing); Nestle, Danone, Estrela, Sadia and Perdigão (food); AmBev and Schincariol (drinks). Some of them have even stopped manufacturing products in their home states, only maintaining their management and administration offices or research centers there (PEREIRA JUNIOR, 2012; ABLAS; PINTO, 2009).

From the regional urban point of view, centralities are created or legitimized and asymmetries are accentuated.The movement points to an uneven distribution of investment and flows, translated by favoring areas where the best conditions of productivity, consumption and public investment already flowed to. In addition the new urban centers, especially small and medium-sized cities, have confirmed their recent capacity to attract companies or industrial groups, increasing the labor supply in the sector and improving the infrastructure, with repercussions for the rhythms of consumption of durable and non durable goods.

Illustrative examples can be seen from reading Cartogram 1, which presents the number of establishments and formal jobs generated by industrial activity in 2013. Firstly, it is possible to observe the strength of the industrial agglomeration on the eastern coast of the Northeast and the polarity exercised by the largest metropolitan centers of the region. In a stretch that extends from Salvador to Fortaleza, in an area that includes the city of Recife, 20 million people agglomerate, generating over $80 \%$ of GDP in the region. The densities are so relevant that the amounts of income and population of the metropolitan areas of the three cities mentioned outnumber those of the states of Alagoas, Paraíba and Rio Grande do Norte (IBGE, 2015).

Entretanto, malgrado o processo de concentração no Nordeste litorâneo, já é possível constatar que novos vetores de expansão produtiva atingem também áreas sem maior tradiçãoindustrial. Tal fato torna-se evidente quando destacamos o incremento de estabelecimentos e de vínculos empregatícios formais da indústria de transformação no sertão e no agreste nordestino, com implicações diretas para a dinâmica urbana. Cidades como Sobral/CE (passou de 93 estabelecimentos e de 2.640 vínculos empregatícios na indústria em 1990, para 195 e 23.485 em 2013), Juazeiro do Norte/CE (de 138 e 2.144 em 1990, para 651 e 10.345 em 2013), Campina Grande/PB (de 363 e 8.644 em 1990, para 833 e 18.884 em 2013), Mossoró /RN (de 150 e 3.579 em 1990, para 478 e 7.126 em 2013), Caruaru/PE (de 257 e 3.689 em 1990, para 1.341 e 13.397 em 2013), Petrolina/PE (de 82 e 
2.172 em 1990, para 361 e 4.409 em 2013),Juazeiro/BA (de 39 e 2.812 em 1990, para 173 e 4.381 em 2013), Vitória da Conquista/BA (de 160 e 1.273 em 1990, para 637 e 8.635 em 2013) eFeira de Santana/BA (de 411 e 7.767 em 1990, para 1.336 e 21.711 em 2013) apresentamimportante fluxo de investimentos nacionais e internacionais a partir da produção industrial dos mais diversos tipos, mormente o de empresas de fabricação de bens de consumo tradicionais, como calçados, alimentos e confecções.

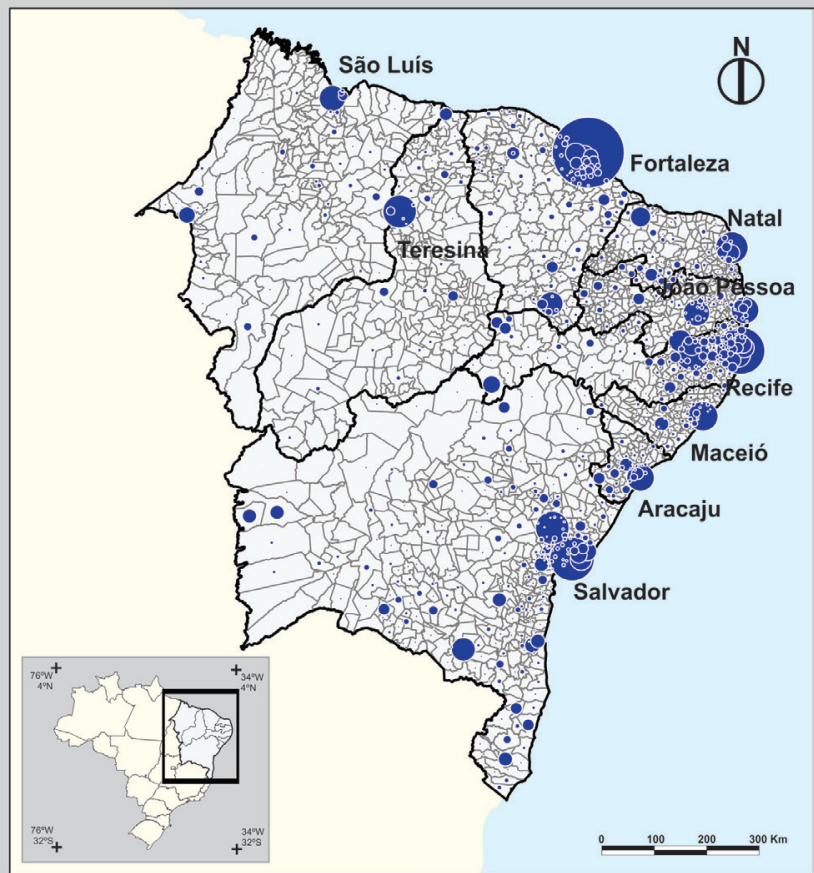

Establishments links in the manufacturing industry (2013)

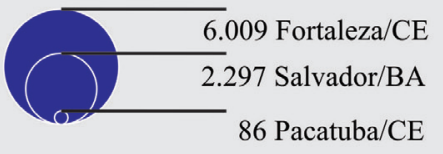

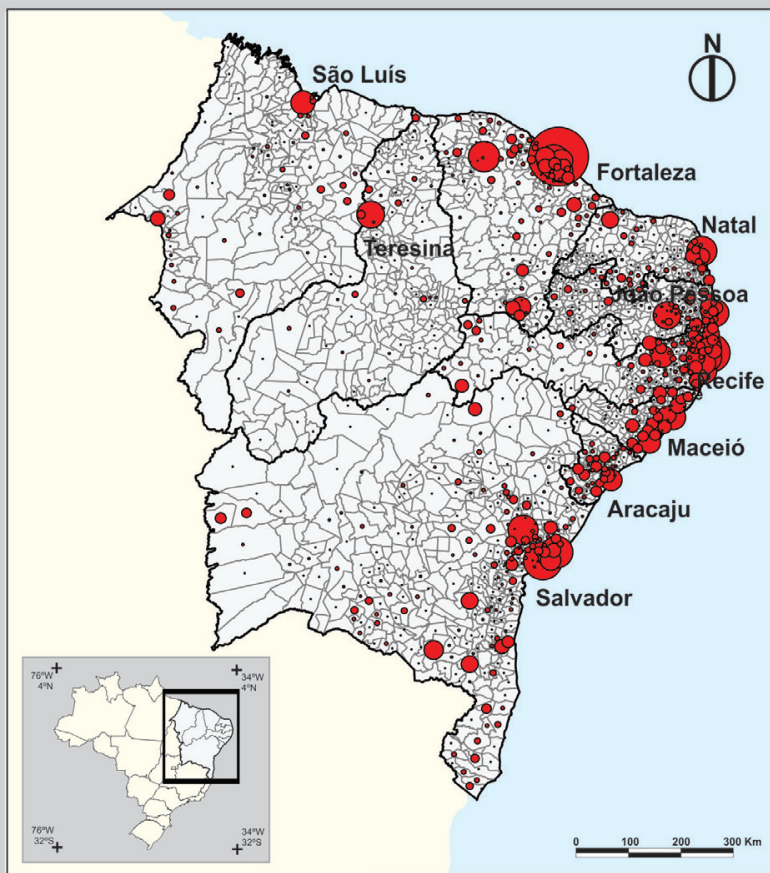

Formal employment links in the manufacturing industry (2013)

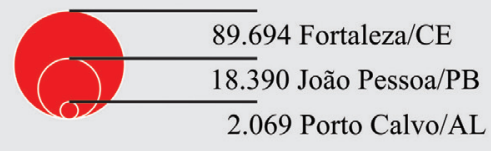

Figure 1 - Establishments and formal employment links in the manufacturing industry - Northeast/2013 Fonte: RAIS/MTE.

With regard to industrial activity there is also concentration. In 2013, the same three metropolitan areas, that is, Salvador, Recife and Fortaleza, accounted for $34 \%$ of all industrial establishments in the region, as well as $37 \%$ of the number of formal workers in the sector. The spatial configuration of the industry follows the flow of the axis of the highways and the arrangement of the cities of the eastern seaboard, always under the command of the largest metropolises. Connecting these three nodes of industrial concentration are the municipalities of their metropolitan regions and some capital cities also located on the eastern seaboard of the Northeast, such as Aracaju, Maceió, João Pessoa and Natal. As exceptions to the coastal boundaries of the region, there are only two empty spaces in the density of industrial installations between Salvador and Fortaleza, one located on the border between the states of Bahia and Sergipe, and the stretches of coast separating the capitals of Ceará and Rio Grande do Norte, as demonstrated in Cartogram 1.

However, despite the process of concentration on the Northeast coast, it can be seen that new vectors of productive expansion have also reached areas without a significant industrial tradition. This fact becomes evident when we highlight the increase of institutions and formal employment contracts in the manufacturing industry in the sertão and in the northeasternagreste, with direct implications for urban dynamics.Cities like Sobral/CE (increased from 93 institutions and 2,640 
employment contracts in the industry in 1990 to 195 and 23,485 in 2013), Juazeiro do Norte/CE (138 and 2,144 in 1990 to 651 and 10,345 in 2013), Campina Grande/PB (363 and 8,644 in 1990 to 833 and 18,884 in 2013), Mossoró/RN (150 and 3,579 in 1990 to 478 and 7,126 in 2013), Caruaru/PE (257 and 3,689 in 1990 to 1,341 and 13,397 in 2013), Petrolina/PE (82 and 2,172 in 1990 to 361 and 4,409 in 2013), Juazeiro/BA (39 and 2,812 in 1990 to 173 and 4,381 in 2013), Vitória da Conquista/BA (160 and 1,273 in 1990 to 637 and 8,635 in 2013) and Feira de Santana/BA (411 and 7,767 in 1990 to 1,336 and 21,711 in 2013) present an important flow of national and international investment in a wide variety of industrial production, especially companies manufacturing traditional consumer goods such as footwear, food and clothing.

Also small and medium-sized cities, some of which take on the role of regional centers, such as Russas/CE (increased from 26 institutions and 99 employment contracts in the industry in 1990 to 183 and 4,868 in 2013), Itapipoca/CE (from 5 and 9 in 1990 to 30 and 2,165 in 2013), Iguatu/ CE (0 and 0 in 1990 to 156 and 3,870 in 2013), Caico/RN (34 and 187 in 1990 to 194 and 1,851 in 2013), Patos/PB (55 and 240 in 1990 to 152 and 1,639 in 2013), Santa Cruz do Capibaribe/PE (28 and 85 in 1990 to 577 and 4,997 in 2013), Toritama/PE (from 7 and 11 in 1990 to 422 and 3,159 in 2013), Arapiraca/AL (83 and 2,151 in 1990 to 244 and 4,665 in 2013), Simão Dias/SE (2 and 218 in 1990 to 24 and 2,840 in 2013), Itabaiana/SE (44 and 462 in 1990 to 192 and 2,700 in 2013), Lagarto/SE (43 and 473 in 1990 to 106 and 3,092 in 2013), Jequié/BA (94 and 2,272 in 1990 to 229 and 6,983 in 2013), Itapetinga/BA (25 and 259 in 1990 to 82 and 7,180 in 2013), among others, gained a productive specialization and took on new roles in the national and northeastern urban network, as they reconfigured their centralities in terms of localized industrial systems or took on a new interurban coordination by attracting external enterprises with headquarters located in states in the South/Southeast or other countries.

In the latter case, it is common for the cities to undergo a restructuring of their economies and infrastructure, completely changing their urban rhythms to accommodate urban capital. The urban economic dynamic often becomes a functional extension of the localized industrial systems or the large enterprises, particularly with the stimulation of the formal employment market in the factories, which as it multiplies, realigns the mobility of people and products, as well as consumption, the real estate market and the established relationships between the city and the region.

In this way, as well as the old industrial centers, like the more consolidated metropolitan areas, some state capitals and small and medium-sized cities have also accelerated their industrial production, stimulating domestic investment and attracting capital from other regions of the country.Each catalyst of these changes - industrial enterprises, the State, different investors, workers - redefines the regional urban space in its own way, coordinating scales, evidencing a new interurban division of labor or organizing land use based on increasingly capitalist precepts.

The spatial urban restructuring that results from these changes is a tributary of the prevailing productive spatial configurations. The urbanization process materializes in space the components established by numerous factors directly linked to these configurations because they tend to define the type of capital invested in the cities, the scope of mechanized industrial production, employment and income generation, the spatial forms built for the best productive flow and the socio-spatial impacts of urban mobility.

We will consider below how these productive configurations tend to affect urbanization and the functional role of some regions and cities in northeastern urban network.

\section{SPATIAL CONFIGURATIONS OF PRODUCTION AS VECTORS OF URBANIZATION IN THE NORTHEAST}

The context in which the renewal of industrial activity in northeastern Brazil occurredmodernized old productive areas, but notably it has strengthened the ability to create new production centers, whose repercussions for urban spatial forms and functions are not irrelevant. 
Within the spatial practices engendered by the productive process, some changes take place that make the scene of regional occupation more complex.Similarly, there is an expansion of the relationship networks of the metropolitan areas and medium and small cities with other portions of space, a phenomenon evidenced by the action of diverse agents who have strengthened their articulation from an increasingly cross-scale arrangement, involving the synchrony/diachrony of local, regional, national and international interests.

However, the materialization of this process has parameters that can be defined from several characteristics, among them the origin and the dimension of the industrial capital implanted, the reach of the spacial circuits of production of the productive genres involved, the role of the State in the execution of the projects, the labor relations used in factories and the specific spatial forms of the productive agglomerations.A systematization of all these logics can define the productive spatial configurations that point to the specific functioning of a certain production process and its regional urban outcome.

As in practice these productive spatial configurations represent the absolute majority of the types of industrial activity highlighted herein, the analysis of its dynamic gives a good sense of the urban restructuring undertaken. A systematization of these configurations organizes a division in the following terms, which are discussed separately below:

1) Localized industrial systems;

2) The industrial zones formed by installing investments of a wide variety of types;

3) Industrial and port complexes.

An analysis of how each of the proposals has unfolded over the past few years is given below.

\section{LOCALIZED INDUSTRIAL SYSTEMS}

Localized industrial systems correspond to a productive spatial configuration aggregating a large number of small and medium enterprises, usually from local capital, involved in a variety of productive stages, with a varied standard of technology, with irregular operation and reduced assistance from administrative modernization and technical policies.Even with the consolidation of a Fordist pattern of industrial production throughout the twentieth century, highlighting the streamlining of production into large establishments, a configuration controlled by a local collective of small and medium-sized companies has always acted in focal points of local and regional life.

With the crisis of Fordism and the emergence of technological innovations, it re-emerged as an alternative to problems with the market, as it was more easily adapted to the demands of productive and labor transformations. Despite an exaggerated optimism regarding localized industrial systems, the fact is that they have greater flexibility to deal with changes in management and production, but they are also formed by poorly capitalized investors who often are unaware of improved productive and commercial strategies and are characterized by great instability.

As these systems do not have the same features in the different places where they are set up, it's difficult to harden the concept that explains them, leaving the comprehension of its contents strongly linked to the idea of diffuse industrial growth, with its own features and socioeconomic conditions related to the predominant local model of accumulation (Reis, 1992; Pecquer, 1993; Courlet, 1993). This is what Reis (1992, p. 55) calls "a productive space characteristic of the intermediate and non-metropolitan forms of development defined simultaneously by: a) their own industrial conditions; b) forms of collective representation; c) socio-economic and territorial conditions related to the predominant social means of production".

One of the important characteristics of localized industrial systems is their capacity to resist with social values and traditional production. In the Northeast region they always reinforce traditional regional elements, supporting the old productive schemes of genres such as clothing, furniture, 
footwear, and small metalworking workshops and plants, the manufacture of bricks and tiles, and the production of food and drinks, among others.

Although some of them grew in metropolitan regions and medium-sized cities, the appropriate environment for them to develop are small cities. As they bring together local social elements that play a crucial role in economic life, by developing these productive systems small cities gain more centrality in the small hinterland,they are no longer just a center for retail distribution and gathering agricultural output.

Thus, localized industrial systems endow northeastern towns with broader productive and commercial functions, usually from a diverse economic dynamic. In the same way, with technological changes and the most recent arrangements of communication and transport networks, it has been possible for some cities with these productive spatial configurations to become functionally specialized centers, articulating the small local capital with large companies with outside headquarters. This is a novelty for the Northeast region, because until the 1990s these systems were isolated and symbolized an economic residue that has been little exploited on a broader scale.

To illustrate this item, we have selected a representative example of this situation.It is a localized industrial system of clothing, textiles, embroidery and garments located in the southern sertão of Rio Grande do Norte state covering cities like Caicó, Serra Negra do Norte, São João do Seridó, Cruzeta, Acari, Jardim de Seridó, Parelhas, Currais Novos, São Fernando, and Jardim de Piranhas Garden, among others.

The region is noteworthy for having a considerable number of productive units and formal employment compared with the state, according to RAIS/MTE (see Cartogram 2), but most of the companies and workers involved in the system are barely registered in official data banks. In municipalities like Jardim de Piranhas, for example, RAIS/TEM showed that in 2013 there were no factories or contracted workers working in clothing and textiles. However, during the field work it was verified that almost half of the local population survives on the manufacturing and sales of small garments and embroidery, involving an average of 200 micro producers, among embroiderers and small weavers.

In this localized industrial system we can point out three sub-specialties: 1) The manufacture of baseball caps (Caicó, Serra Negra do Norte and São José do Seridó); 2) The production of weaving and embroidery (Jardim de Piranhas, São Fernando, Jucurutu, Caicó, Currais Novos, São João do Sabugi, Ouro Branco, Santana do Seridó, Parelhas and Carnaúba dos Dantas); 3 ) The production of pieces for garments (Cruzeta, Acari, Jardim de Seridó, São José do Seridó, Parelhas and Currais Novos).

1) In the manufacture of baseball caps, the work of 64 small or medium-sized productive units is noteworthy, divided between the municipalities of Caicó (48) Serra Negra do Norte (15) and São José do Seridó (1) (LINS, 2011; REDESIST, 2010). These are small factories or workshops located in the neighborhoods of the three cities, with a monthly production of between 10 and 130 thousand units, recruiting dozens of workers who perform a home/work movement several times a day. Production is usually negotiated by intermediaries with buyers in the region, from other municipalities in Rio Grande do Norte (Mossoró and Natal), Brazilian states (such as Pernambuco, Goiás, Distrito Federal, Rio Grande do Sul, Rio de Janeiro and São Paulo) and even other countries (Uruguay and Spain). The quality of the product is quite diverse and varies according to the type of client and the spatial production circuit of each manufacturer; it tends to improve in proportion to the distance from the consumer market. In this way, some companies have a national or international reach, and when this happens the cross-scale relationships involve sellers and buyers from various states. Regarding urban space, the small towns of Serra Negra do Norte and São José do Seridó have a modest morphology, the few shops are located in the central area, taking advantage of the infrastructure of these areas. In Caicó the distribution is more complex as the 48 units are in several neighborhoods, including 
Paraíba, Barra Nova, Castelo Branco, João XXIII etc., forming an urban morphology that is sometimes the expression of flows created by industrial activity, especially the movement of vehicles and workers. As the functions are subdivided between sewing, embroidery, painting, finishing and administration inside the urban space itself, the production of baseball caps has a very particular influence on the logic of the cities, accelerating their rhythms (LINS, 2011; REDESIST, 2010).

2) The production of weaving and embroidery is another sub specialization of the localized industrial system, in fact it is the oldest, the result of traditional knowledge developed through the processing of cotton. There are around 250 small producers, many of them family units who work in residences using rudimentary instruments, they are mainly located in Jardim de Piranhas, Caicó, CurraisNovos, São João do Sabugi and OuroBranco. They are noteworthy for the production of dishcloths, mats for the bathroom, hammocks, rugs, throws, bags, aprons, cushions, coffee strainers, among others, manufactured and distributed without any greater technical and technological rationalization or improvements. The circulation is mainly local, but there is a partnership with garment and baseball cap producers that has accelerated the productivity and the volume of the negotiated products, so that the products meet the demands of clients located in other regions. As it is a locally created specialization, the bigger impact of the movements reaches principally the small cities and locations involved in the production. Nevertheless, for the local urbanization these impacts are representative, as according to Sebrae, the total of jobs created reaches almost four thousand in periods of high demand (REDESIST, 2010).
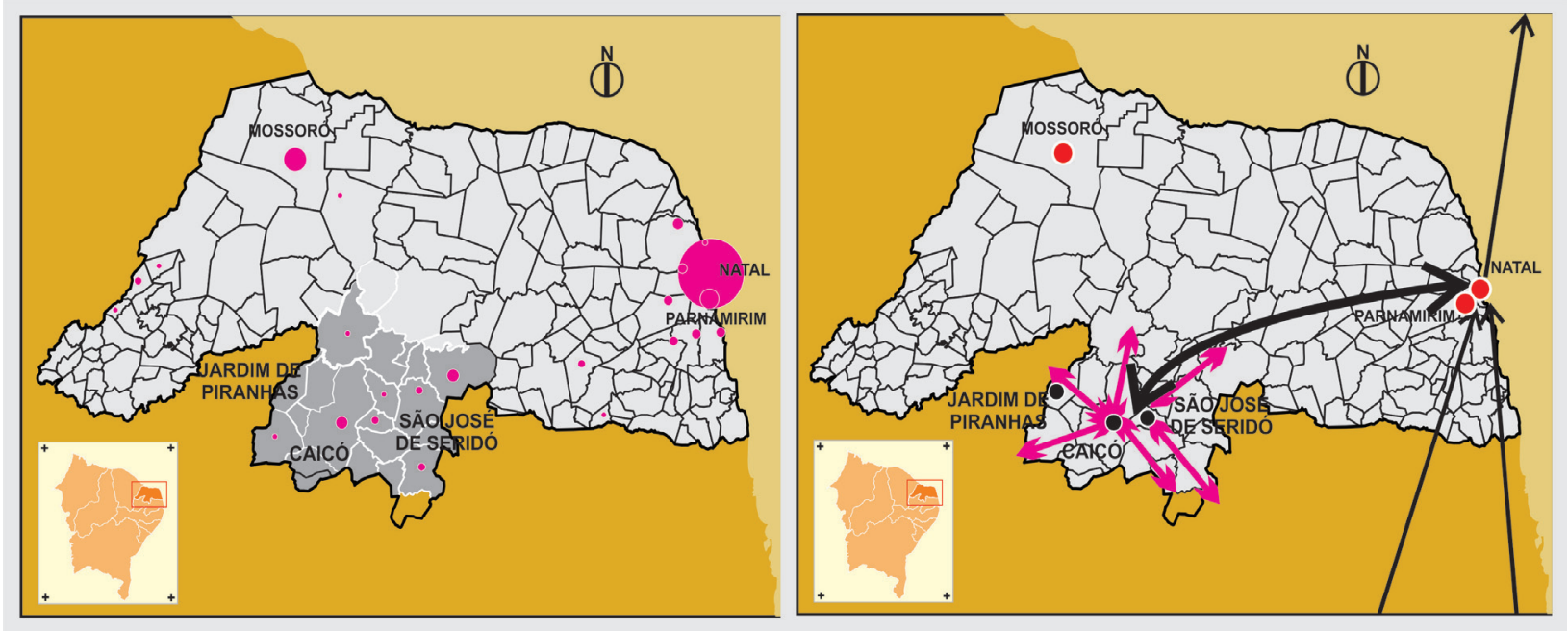

Figure 2 - Establishments and spatial production circuits of the localized industrial system of garments, textiles, embroidery and clothing in Seridó/RN

3) Developed from the improvements in the production of textiles and embroidery, a group of local producers invested in the manufacture of pieces of clothing and the activity spread to various cities of the Seridó Potiguar, among them São José do Seridó, Cruzeta, Acari, Parelhas, Jardim de Seridó and Currais Novos.Of modest coverage and local in scope, in the 2000s the production received increments from industrial policies and cooperation with external companies, a situation that greatly changed the profile of the production process.Many of these producers have been subcontracted by three companies with large factories in Natal and neighboring municipalities - Guararapes, Hering and RM-Nor - and the result was a very unique circuit of strong production coordination within the state and the far-reaching distribution of goods for consumption. Usually the municipal administrations take responsibility for the infrastructure by installing warehouses, the state government trains the workers and the large 
companies commit themselves to negotiate pieces or complete garments for their collections with local producers. Information obtained during field studies shows that in 2015, around 50 producers (or factions as they are called in the region) are integrated into this circuit, which highlights principally the factories located in São José do Seridó (13), Cruzeta (7) andAcari (6).Within the interurban and intra-urban space, in addition to an extensive relationship with several states in Brazil where Hering, Guararapes and the RM-Nor distribute their products, the production dynamics of the confections directly affects the small local towns. The work rhythm is rationally established, factory hours and the accelerated movement back and forth have imposed new conditions on the urbanization of the sertão in Rio Grande do Norte.

In general, the localized industrial system of garments, textiles, embroidery and clothing in the sertão in the south of the state of Rio Grande do Norte is representative of the new urbanization in the Northeast conditioned by industry. It operates basedon particular relationships of production and labor and is directly related to the local patterns of accumulation, but recently they have gained a wider cover and tend to be established through coordination between increasingly cross-scale agents.

\section{INDUSTRIAL ZONES}

The transformation that demarcated a new phase for productive activity in the Northeast began in the 1990s and was linked, above all, to the transfer of genres from the traditional industries from other parts of Brazil to the region. Some companies manufacturing footwear, electrical appliances, clothing, textiles, food, beverages and packaging, among others, sought the northeastern states and set up their production facilities in the capitals or in the cities in the interior. They were mainly interested in the offer of low cost labor, fiscal incentives and the greater possibility of making production and labor relationships more flexible. In turn, in synchronization with the world, they have articulated the demand of local political and economic interests with the capacity acquired by productive capital to accelerate the movements through new information technologies. This made the global/national/local relationship an integrated network capable of serving the hegemonic interests of accumulationexpandedin the short-term.

This newly attracted industrial capital introduced modern industrial activity to metropolitan peripheries or medium and small cities; it was characterized by the acceleration of factory time, materialized in production areas formed from the installation of one or more production units.Due to the important role that state governments played in this productive organization, by offering tax subsidies, but also raising the necessary infrastructure for the setting up of factories, it can be said that the good performance in the consolidation of these industrial zones took place through subsidized actions.

Many genres were involved in this movement, as indicated above, and in the same way, there were many northeastern states that absorbed these strategies for attracting capital, but we have selected the case of the footwear industry in Ceará as the empirical object of this study, as one of the most complete examples of this productive spatial configuration. In addition, its effects on urban restructuring were effective, confirming the capacity on industry to modify spatial practices, redefining them as a function of productive demand and consumption.

The implementation of the footwear-producing factories also illustrates a differentiated pattern in the interurban division of labor. This is because, by taking on a more diffuse profile in the territory of Ceará state, even settling in cities with a poor infrastructure, it revealed that it was possible for modern industry to keep pace with the rhythms of accumulation, whilst at the same time benefiting from cheap labor in small and medium-sized cities, and the new technologies of production and information, all coordinated as a network.

Therefore, industrial zones are the spatial form of this productive configuration, and in the case of Ceará's footwear industry, they bring together large production units, which resemble the 
Fordist concept of the River Rouge factory, the huge unit the Ford Motor Company installed in the United States in the 1930s. These plants are scattered throughout the Metropolitan Region of Fortaleza and municipalities in the state, generating a significant number of formal jobs in areas formerly dominated by subsistence agriculture and the trade and services linked to the lower circuit of the urban economy.

The state's territory has been widely incorporated as a result of its adaptability to the demands of footwear production companies. These, in turn, have restructured internal production circuits, particularly by fragmenting the stages of production in different portions of space, favoring some regional specialization. The result has been the pulverization of factories producing footwear in 32 municipalities.

In the organization of regional urban space there are many strategies to effectuate these mechanisms. One of the most important is associated with the actions of major business groups such as Grendene, Vulcabrás and Dakota, who preferred to settle in cities in the metropolitan periphery or medium-sized cities and regional centers.

The structure of Ceará's urban network and the greater centrality of some cities have exerted a strong influence in attracting enterprises.Despite the virtual absence of subsidized establishments from out of state in cities like Fortaleza and Juazeiro do Norte, the municipalities of Sobral, Horizonte, Maranguape, Quixadá, Quixeramobim, Russas, Iguatu and Crato, which are composed of important urban agglomerations in the state, have received the biggest production units. Why this preference? In fact, Grendene, Vulcabrás and Dakota account for the absolute majority of the state's production of footwear $(82.3 \%)$ and their plants are vast industrial production complexes, with huge warehouses for raw materials and numerous sectors where activities such as sewing, assembly and processing of synthetic materials, and others are carried out.

To meet this demand, centralized electricity, communication and water and sewage networks are needed. In addition, the number of contracted workers who circulate daily through the factories is over 45 thousand, which requires an infrastructure capable of meeting such a flow. In the same way, buses, trucks and other vehicles that ensure the smooth operation of the units cannot circulate efficiently without a structured road network. Finally, as the main markets for the products are out of state or overseas, added to all this is the need for better coordination with the transport nodes (ports and airports), which set limits to the pattern of location within the territory (see Cartogram 3).

Briefly, the large productive units of the footwear industry in Ceará, which migrated mainly from Rio Grande do Sul and São Paulo, were unable to do without a certain urban structure to provide them with the right conditions to accomplish a high-volume production and distribution. This conferred on the metropolitan periphery, medium-sized towns and regional centers inCeará the ability to concentrate the largest and most important industrial footwear plants in the state.

The strategies described herein define the directions of the productive structure responsible for the creation of industrial zones in the Northeast.Like the example cited for the footwear industry, it would also be possible to highlight the regional and urban effects of investments by the Alpargatas group in Paraíba (Campina Grande, João Pessoa and Santa Ines), the Dakota group in Sergipe (Simões Filho) and the Vulcabrás/Azaleia and Grendene groups in cities in the state of Bahia (mainly Itapetinga and Teixeira de Freitas).

Similarly, other industrial genres consolidate the characteristics of this productive configuration space, concentrating their establishments in urban environments suited to their productive efficiency.Among them can be cited the textile, metalworking, and appliances industries that prefer to settle in metropolitan peripheries (Maracanaú/CE, São Gonçalo do Amarante/RN, Abreu e Lima/ $\mathrm{PE}$, etc.)or the clothing, food, beverages and packaging industries that select cities of different sizes and functionalities to locate their plants (Mossoró/RN, Campina Grande/PB, Caruaru/PE, and Feira de Santana/BA, etc.). 


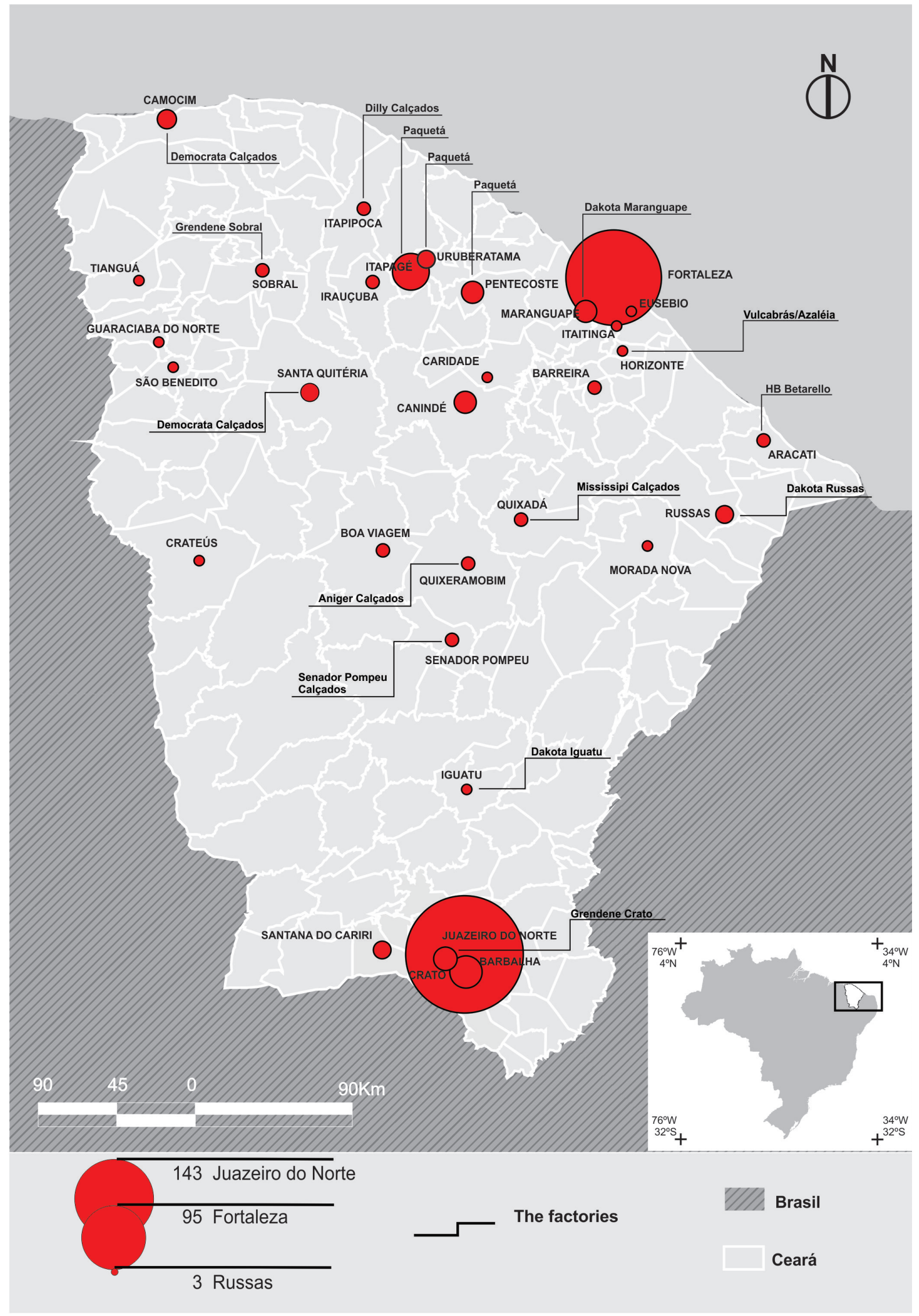

Figure 3 - The distribution of the factories of the main footwear companies located in the territory of Ceará 
In this context, space is no longer an obstacle to the search for better working conditions and productivity and cities feel the effects of industrialization as a vector to transform the economy and society.If on the one hand, they have become important profitability mechanisms for companies able to integrate large circuits of production and consumption;on the other, they experience the intensity of modern productive rhythms, being reinserted into the arrangement of the urban network, reconfiguring their traditional features.

\section{INDUSTRIAL AND PORT COMPLEXES}

It is essential for the expanded accumulation strategies in industrial production that large production and logistics complexes be created, and along with them the effective material and immaterial fluidity of space. This demarcated the economic setting that reaffirmed "Fordism" as a predominant regime of accumulation in the twentieth century. Industrial complexes, especially heavy industry, such as steel, oil refining and ship building; but also the supply chains of the consumer goods industries, such as automotive and metalworking, that take advantage of the clustering of these centers, have been instrumental in the dynamism of the Brazilian economy in the last five decades.

The assembly of these complexes has always stimulated the action of numerous agents, all interested in shaping the spaces able to receive such investments. This is a significant industrial structure in which the heavy productive activities modeled regional urban spaces and, in a dialectical movement of dynamic inertia, regional urban areas directly influenced the industrial activities. Metropolitan environments were the most favorable for the development of these dynamics, because they have the economic, demographic, social and political centrality needed for this.

The political aspect was crucial for the installation and consolidation of this productive spatial configuration in northeastern Brazil.The State was the decisive agent for leveraging resources and installing the infrastructure, as it had promoted heavy industrialization since the first regional planning actions of the Superintendency for the Development of the Northeast (SUDENE).Until the 1970s, only Bahia had felt the impact of these investments, consolidated through the implementation of industrial enterprises targeting petrochemical and metalworking production to complement industry based in the Center-South of the country (IPEA, 2001). The main projects were the Landulfo Alves refinery (RLAM), installed after the discovery of oil and gas fields in the Reconcavo Baiano, the Aratu Industrial Center (CIA), a metalworking park that resulted from the federal policy for industrial decentralization in the 1960s; and the Camaçari Petrochemical Complex (COPEC), created as part of the federal government's Second National Development Plan (II PND) (IPEA, 2001). These were all initiatives by the State planned in line with the attraction of foreign capital, which turned Bahia into a state of major industrial production of intermediate commodities, installing a complex of great productive specialization in the metropolitan area of Salvador, with impacts on the urban dynamics of Salvador, Candeias, Camaçari, Simões Filho, and Madre de Deus, among others.

This experience, however, was not reproduced in other states, despite the political efforts of Pernambuco and Ceará to attract enterprises of this nature. The fiscal crisis of the 1980s and 1990s and the federal government's retraction in stimulating large industrializing actions impeded the effectuation of other initiatives with this profile. Even so, the political mobilization to attract investments from the petrochemical and steel industry has always been on the agenda of demands of numerous regional leaders.

The debate resurfaced after the resumption of the national-development model supported by President Luiz Inacio Lula da Silva in 2002 (MORAIS; SAAD-FILHO, 2011).In fact, the consolidation of the proposal occurred during the President's second term (2007-2010) and, as highlighted by Morais and Saad-Filho (2011), bears some similarities to the developmentalism of Juscelino Kubitschek, especially when investing in the formation of productive capital open to intervention by the State, foreign enterprises and domestic enterprises.Of course, President Lula's developmentalism was inserted in the context of the new configuration of capitalist accumulation, which makes 
it more vulnerable to the impositions of a globalized and deregulated market.But the important thing here is to consider the recovery of the lead role by the National State, especially when it finances and invests in productive capacity in order to generate economic growth.

As a result of these changes, the Northeast has been awarded another two major assemblages, namely the industrial and port complexes of Suape, in Pernambuco state and Pecém, in Ceará.The spatial difference from the Bahia project is that at the complexes of Suape and Pecém, large tracts of land were expropriated by the State so that the industrial plants, infrastructure equipment and port terminals could be compacted and consolidated into a single complex.

Both projects have considerable economic and regional urban impacts, assembled from the construction of steel and petrochemical complexes with the easy distribution of goods abroad.They are industrial and port spaces with a comprehensive infrastructure and access to railway and road transport, built with major resources from the federal government in partnership with the governments of these states in an attempt to also consolidate intermediate supply chains and metalworking companies with a large volume production.

Despite the Industrial and Port Complex of Pecém (CIPP) still being consolidated, the Industrial and Port Complex of Suape (CIPS) has been through significant transformations in the last eight years, establishing itself as one of the main industrial centers of the Northeast and Brazil. For this reason we will analyze it to understand more about the characteristics of this productive spatial configuration.

Even with earlier initiatives, the delimitation of the area for the installation of the Industrial and Port Complex of Suape took place in 1974. It is located $40 \mathrm{~km}$ south of Recife, in the municipalities of Ipojuca (25\%) and Cabo de Santo Agostinho (75\%), as a result of the expropriation of land from the former sugar plantations, millsand areas set aside for land reform, occupied by small farmers. In all, it has an area of 13,500 hectares (see Cartogram 4), with portions reserved for large industrial manufacturing plants, roads, port terminals, and environmental reserves, among others (SUAPE/GOVERNMENT OF PERNAMBUCO, 2010).

Until the early 2000s, the complex had not undergone major interventions, serving in practice to concentrate the facilities of the companies BR Distribuidora, Shell, Texaco and Esso, as well as the installation "of medium-sized companies with low technological complexity, little demand for professional qualifications and a limited irradiation capacity in the regional economy"(SANTOS, 2012).

Effective changes occurred after 2005, with the announcement of the creation of the Abreu e Lima Refinery, through a partnership between Petrobras and Petróleos de Venezuela, S.A(PDVSA), and from the launch of the Growth Acceleration Program (PAC) by the federal government.Since then numerous public ( $\mathrm{R} \$ 3$ billion) and private ( $\mathrm{R} \$ 50$ billion) investments have been consolidated until 2015 and are responsible for the assembly of a significant number of industrial, port and infrastructure equipments, among which could be cited:1) Abreu e Lima Refinery (Petrobrás), 2) Petroquímica Suape (Petrobrás), 3) South Atlantic Shipyard (Transpetro), 4) Vard Promar Shipyard, 5) Steel Company Suape, 6) Energetica Suape (thermal), 7) Mossi \& Ghisolf manufacturers of PET resins, 8) Impsa Wind Power (manufacturing wind turbines), 9) Bunge (refining of vegetable oils, production of margarine and wheat mill), 10) Tecon Suape (port logistics), 11) Solid Bulk Terminal, 12) Grain Terminal, 13) Suape Business Centre, etc. (SUAPE/GOVERNMENT OF PERNAMBUCO, 2015).In 2015, the complex had 101 companies in operation and dozens more being installed, all responsible for providing about 25 thousand formal jobs.

Figure 4 shows the investments made between 2007 and 2013 in some municipalities in Pernambuco state, confirming the attraction of Cabo de Santo Agostinho and Ipojuca(they made between $\mathrm{R} \$ 10$ and 60 billion in the period), precisely the municipalities where the companies in the Industrial and Port Complex of Suape are installed.As can be seen, besides these two municipalities, only Goiana received investments of over R $\$ 10$ billion, due to the installation of a production unit 
by Fiat, which manufactures the Jeep line of cars, also attracted by the agglomeration economy of the CIPS. Thus the complex attracted more investment than the capital Recifeduring the period; it also surpassed the investments of the other municipalities of the metropolitan area (FIEPE, 2013).

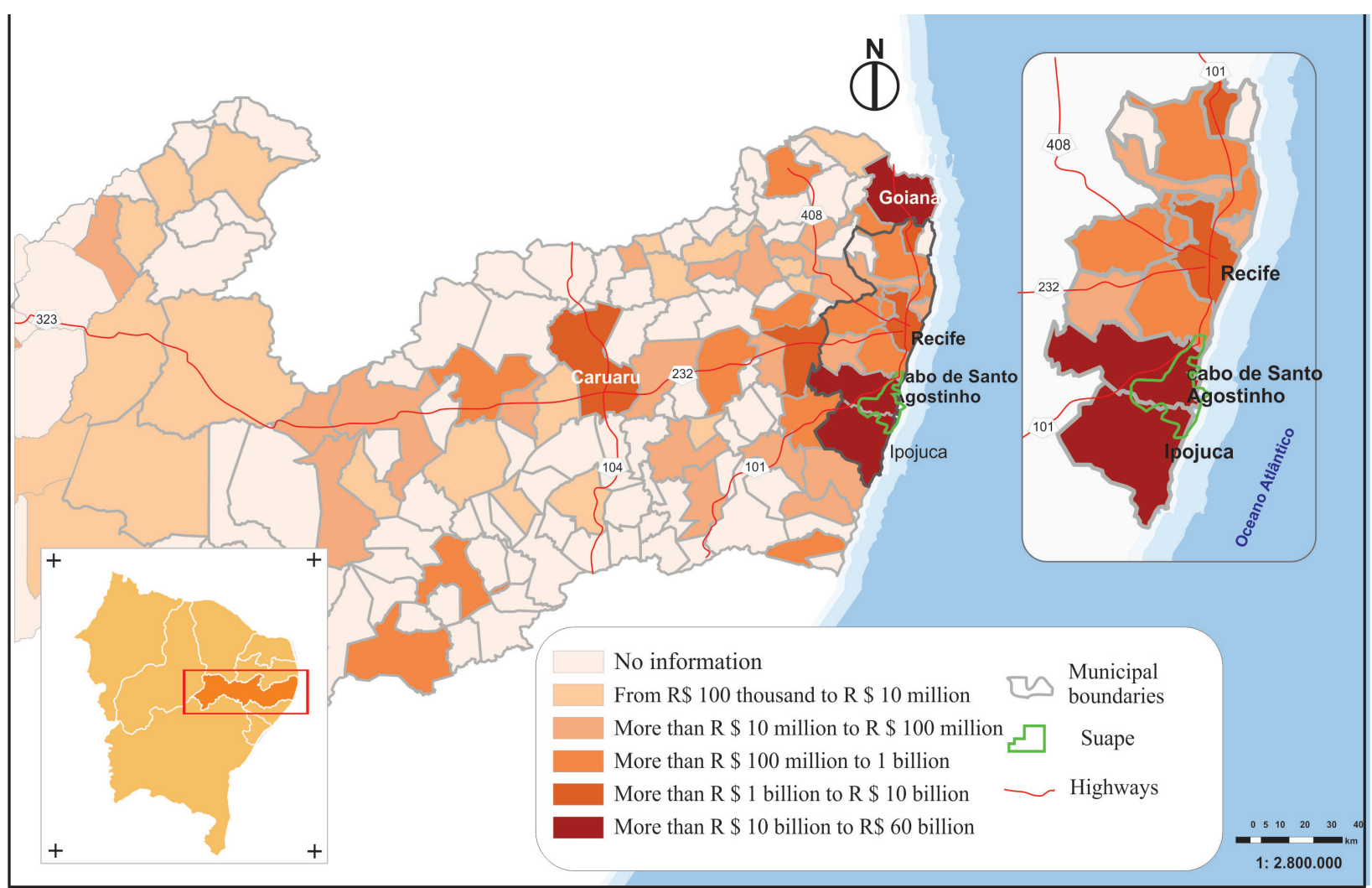

Figure 4 - Value (R\$) of the industrial investments in some municipalities of Pernambuco (2007/2013) Source: FIEPE/Ceplan.

All these dynamics greatly altered the configuration of the Metropolitan Region of Recife. If the changes in this metropolitan environment had already been significant with the impact felt by investment in trade, services and construction, the advent of the Industrial and Port Complex of Suape caused unprecedented changes in the regional urban space. The spatial interactions have reached a much wider articulation with people, information and goods gaining cross-scale fluidity. Networks of relationships integrate local, regional, national and international companies and institutions, in a complex circuit in which the rules are increasingly marked by organizational solidarity.

Municipalities directly affected by the effectuation of investments, such as Cabo de Santo Agostinho, Ipojuca, Jaboatão dos Guararapes, Moreno and Escada, suffer from a new wave of migratory flows and the conversion from rural land use into urban use.Large numbers of people now inhabit the poor and neglected periphery, especially on steep slopes, mangroves swamps, wetlands or other areas unsuitable for residential settlements.In the same way, the construction sites that gather thousands of workers become small nuclei of precarious settlements without any infrastructure, expanding the pockets of poverty.

The report below from the Jornal do Comércionewspaper confirms this situation:

People perched on the hill slopes, balancing on stilts, squeezing into shacks, invading areas of environmental preservation. Houses built bymembers of the community at dawn to evade inspection.A lack of housing. Land is getting scarcer and more expensive. According to calculationsby the municipalities ofCabo de Santo Agostinhoand Ipojuca the housing deficit in the two cities is almost 25 thousand units. This shortage is exacerbated by the invasion of a floating population of 45,000 people who arrived along with the works inSuape.Real estate speculation and a low offer have made the price of rent rocket and accelerated a movement of slum creation. (JORNAL DO COMMÉRCIO, 2015). 
These ongoing changes confirm the impacts felt by the urbanization process stimulated by the assembly of the industrial and port complex. The effects are contradictory and tend to restructure the metropolitan location of industrial production, also realigning flows, infrastructure and residential settlement areas.Finally, the process demonstrates how a productive spatial configuration of this nature can redimension economic dynamics, and how its effects can redefine the role of cities and the metropolitan region, supporting profound changes in urban structure and geographical articulation.

\section{FINAL CONSIDERATIONS}

The context in which forces of acceleration of objects and flows are materialized in new industrial space, resulting from the hegemony of competing interests, engenders an unprecedented mobility on different geographical scales by integrating urban and regional systems through a network of relationships controlled by productive investments eager for profit.

The effects of these changes in Brazil are worth emphasizing, in particular on its urbanization process, which controls the expansion of modern industrial establishments, the interurban division of labor, the aspects concerning productive restructuring and its consequences for the coordination between cities and regions, the intensity of the migratory flows and the inclusion of new and different areas in industrial productive processes.

The regional urban space is significantly altered, resulting in the redefinition of the central roles of some cities and changes in the functioning of traditional arrangements in the Brazilian urban network, which are now delineated by different centralities and connections in the ambit of industrial activity. In this article, we have discussed how three productive spatial configurations were responsible for restructuring the regional urban space in the Northeast of the country, with an emphasis on the empirical cases that represent this transformation, which are: 1) The localized industrial system of clothing, textiles, embroidery and garments in Seridó /RN;2) The industrial zones formed by the installation of footwear factories in Ceará; and 3) the Industrial and Port Complex of Suape/PE.

The three configurations have an important characteristic in common, which is directly linked to the aforementioned set of transformations: they increasingly legitimate a spatial and urban arrangement that subverts the logic of continuity, establishing cross-scale relationships in the ambit of production and the circulation of information and products. At the same time, a change of meaning occurs in the urban network and the roles of the cities affected by industrial investment, in a way that redefines its centralities, commanding a new mobility of people and merchandise and diversifying the spatial circuits of inputs/industrial products.

These are striking effects that affect the old forms of consolidation and industrial/urban interaction in the Northeast, causing older manufacturing areas to specialize and new production areas to incorporate different meanings, becoming centers for growth.

Finally, the most recent restructuring of industrialized urban space marks a set of transformations that range from locally created productive specializations, responsible for producing industrial systems located in regional centers and small towns; to the emergence of factors attracting investments in metropolitan regions or medium-sized cities, able to stimulating the creation of zones and integrated industrial complexes in a large built area, offering cheap labor and service goods, with access to ports, airports and railways .

They symbolize the new content of urbanization that is conducted by the industrial activity in the Northeast, which restructures the role of cities, stimulating or redefining traits of inequality, as well as spatially reconfiguring the ties of submission and command in the new regional urban arrangement. 


\section{BIBLIOGRAPHIC REFERENCE}

ABLAS, Luís Augusto de Queiroz; PINTO, Rafael Fontana. Nordeste Brasileiro: crescimento e dinâmica espacial no período 1970-2008. Revista Econômica do Nordeste, Fortaleza, v.40, n.4, p.821-832, 2009.

BARROS, André Paulo de; SILVEIRA, Karla Augusta. A produção do espaço rural urbano e seus rebatimentos nos conflitos socioambientais na área de Suape, Pernambuco - Brasil. Cad. CERU [online], v. 21, n.1, p. 163-179, 2010.

CONFEDERAÇÃO NACIONAL DA INDÚSTRIA (CNI). Perfil da indústria nos estados 2014. - ed. rev. - Brasília: CNI, 2014. 214 p.

CONFEDERAÇÃO NACIONAL DA INDÚSTRIA (CNI). Revista Indústria Brasileira, Brasília, n.86. Encarte especial "Nordeste". Brasília: CNI, 2008.

CORRÊA, Roberto Lobato. Perspectivas da urbanização brasileira - uma visão geográfica para o futuro próximo. In: PEREIRA, Elson Manoel. DIAS, Leila Christina Duarte. As cidades e a urbanização no Brasil. Florianópolis: Editora Insular, 2011.

COURLET, Claude. Novas dinâmicas de desenvolvimento e sistemas industriais localizados (SIL).Ensaios FEE. Porto Alegre. Volume 01. Número 14. 1993. p. 09 a 25.

DE NEGRI, B. Concentração e desconcentração industrial em São Paulo (1880-1990). Campinas: IE-Unicamp, 1994. (Tese de Doutorado em Economia).

DINIZ, Clélio Campolina. CROCCO, Marco Aurélio. Reestruturação econômica e impacto regional: o novo mapa da indústria brasileira. Revista Nova Economia, Belo Horizonte, v.6, n.1, p.78-103, 1996

FEDERAÇÃO DAS INDÚSTRIAS DO ESTADO DE PERNAMBUCO (FIEPE). Proposta de uma política industrial para o estado de Pernambuco. Recife: FIEPE, 2013.

GÓIS SOBRINHO, Ednaldo Moreno. AZZONI, Carlos Roberto. Aglomerações industriais relevantes do Brasil. In: Nereus/USP: São Paulo, 2014.

INSTITUTO BRASILEIRO DE GEOGRAFIA E ESTATÍSTICA(IBGE). Pesquisa Industrial Mensal Produção Física 2013 - Brasil. Disponível em http://www.ibge.gov.br/home/estatistica/indicadores/industria/ pimpf/br/default.shtm. Acesso em Fevereiro de 2015.

INSTITUTO BRASILEIRO DE GEOGRAFIA E ESTATÍSTICA (IBGE). Estimativas da população residente para os municípios e para as unidades da federação brasileiros com data de referência em $1^{\circ}$ de julho de 2015. ftp://ftp.ibge.gov.br/Estimativas_de_Populacao/Estimativas_2015/estimativa_dou_2015.pdf. INSTITUTO DE PESQUISA ECONÔMICA APLICADA (IPEA). Caracterização e tendências da rede urbana do Brasil. volume 4: redes urbanas regionais - Norte, Nordeste e Centro-Oeste. Brasília: IPEA, IBGE, UNICAMP/IE/NESUR, 2001.

JORNAL DO COMMÉRCIO. Documento Suape 2015. Disponível em http://especiais.jconline.ne10.uol. com.br/documento-suape-2015/. Acesso em 29 de junho de 2015.

LENCIONI, Sandra. Reestruturação urbano-industrial no estado de São Paulo: a região da metrópole desconcentrada. Espaço e Debates, São Paulo, n.38, p.54-61, 1994.

LINS, Zara de Medeiros. Circuitos espaciais de produção da atividade boneleira: o uso dos territórios de Caicó, Serra Negra do Norte e São José de Seridó. Natal: Programa de Pós-Graduação e Pesquisa em Geografia, 2011. (Dissertação de Mestrado).

MINISTÉRIO DO DESENVOLVIMENTO, INDÚSTRIA E COMÉRCIO EXTERIOR (MDIC). Dados estatísticos - 2012. Disponível em: <www.secex.mdic. gov.br>. Acesso em 28 março de 2015.

MORAIS, Lécio; SAAD-FILHO, Alfredo. Da economia política à política econômica: o novo-desenvolvimentismo e o governo Lula. In: Revista de Economia Política, vol. 31, nº 4 (124), pp. 507-527, outubro-dezembro/2011.

OLIVEIRA, Roberto Véras de. Suape em construção, peões em luta: o novo desenvolvimento e os conflitos do trabalho. CADERNO CRH, Salvador, v. 26, n. 68, p. 233-252, Maio/Ago. 2013.

PECQUEUR, Bernard. Sistemas industriais localizados - O exemplo francês. Ensaios FEE. Porto Alegre. Volume 01. Número 14. 1993. p. 26 a 48. 
PEREIRA JÚNIOR, Edilson (2012). Território e economia política: uma abordagem a partir do novo processo de industrialização no Ceará. São Paulo: Editora da Unesp/Selo Cultura Acadêmica. Disponível em http://www.culturaacademica.com.br/.

REDESIST (Rede de Pesquisa em Sistemas e Arranjos Produtivos Locais). Projeto - Análise do mapeamento e das políticas para Arranjos Produtivos Locais no Norte, Nordeste e Mato Grosso e dos impactos dos grandes projetos federais no Nordeste. Notas Técnicas 02 e 05: Caracterização, análise e sugestões para adensamento das políticas de apoio a APLs implementados no estado do Rio Grande do Norte. Rio de Janeiro: Redesist/BNDES/UFRN/Funpec, 2010.

REIS, José. Os espaços da indústria: a regulação econômica e o desenvolvimento local em Portugal. Porto: Edições Afrontamento, 1992.

SANTOS, Milton. A urbanização brasileira. São Paulo: Editora da Universidade de São Paulo, 2005.

SANTOS, Milton. SILVEIRA, Maria Laura. Brasil: território e sociedade no início do século XXI. 3.ed. Rio de Janeiro: Record, 2001.

SANTOS, Valdeci Monteiro dos Santos. Entrevista concedida ao IHU On-Line, 24/04/2012. (www.ihu. unisinos.br/entrevistas/508579-suapeum-desafio-para-pernambuco-entrevista-especial-comvaldeci-monteiro-dos-santos). Acesso em janeiro de 2015.

SPOSITO, Maria Encarnação Beltrão. Metropolização do espaço: cidades médias, lógicas econômicas e consumo. In: FERREIRA, Álvaro; RUA, João; MATTOS, Regina Célia. Desafios da metropolização do espaço. Rio de Janeiro: Consequência, 2015.

SUAPE/GOVERNO DE PERNAMBUCO. PAC/Complexo Suape: Relatório - Março de 2010. Disponível em: http://www.suape.pe.gov.br/pdf/relatorioObraSuapeMarco2010.pdf. Acesso em janeiro de 2015.

SUAPE/GOVERNO DE PERNAMBUCO. Complexo industrial e portuário de Suape: Pernambuco preparado para novos negócios.Recife: CIPS, 2015.

Submitted december 2015 Accepted january 2016 